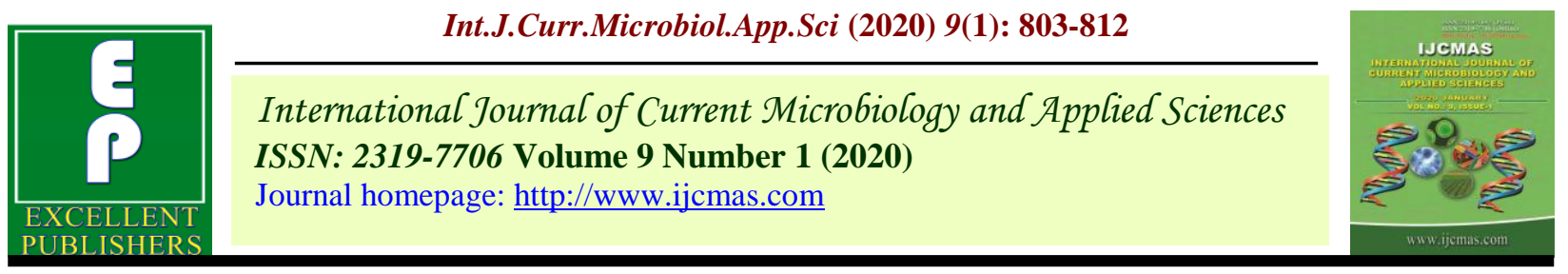

Original Research Article

https://doi.org/10.20546/ijcmas.2020.901.086

\title{
Sowing Time and Zn Application Effects on Productivity and Zn Use Efficiency of Wheat (Triticum aestivum L.) Varieties
}

\author{
Amit Kumar ${ }^{*}$, Shiva Dhar ${ }^{2}$, Anchal Dass ${ }^{2}$ and Ranjana ${ }^{3}$ \\ ${ }^{1}$ ICAR-Indian Institute of Farming Systems Research, Modipuram, Meerut 250 110, India \\ ${ }^{2}$ ICAR-Indian Agricultural Research Institute, New Delhi 110 012, India \\ ${ }^{3}$ Govind Ballabh Pant University of Agriculture \& Technology, \\ Pant Nagar, U. S. Nagar 263 145, India
}

*Corresponding author

\begin{tabular}{|l|}
\hline Ke y w o r d s \\
Very late sowing, \\
$\begin{array}{l}\text { Wheat varieties, } \\
\text { Zinc application } \\
\text { and Zinc use } \\
\text { efficiencies }\end{array}$ \\
\hline Article Info \\
\hline $\begin{array}{l}\text { Accepted: } \\
\text { 15 December } 2019 \\
\text { Available Online: } \\
\text { 20 January } 2020\end{array}$ \\
\hline \hline
\end{tabular}

A B S T R A C T
Field studies were performed during rabi seasons of 2013-14 and 2014-15 at Indian Agricultural Research Institute, New Delhi to examine the influence of sowing time and $\mathrm{Zn}$ application on productivity and $\mathrm{Zn}$ use efficiency of wheat [Triticum aestivum (L.) emend. Fiori \& Paol.] varieties. Experiment was carried out in split-plot design and replicated thrice. Two factors sowing times (normal and very late) and wheat varieties (HD 2967, WR 544 and HD 3059) were taken in main-plots whereas third factor i.e. $\mathrm{ZnSO}_{4} .7 \mathrm{H}_{2} \mathrm{O}$ application (control, $25 \mathrm{~kg} / \mathrm{ha}$ soil application, three foliar sprays @ $0.5 \%$ at boot, anthesis and grain filling stage, $25 \mathrm{~kg} / \mathrm{ha}$ soil application + one foliar spray @ $0.5 \%$ at anthesis) was kept in sub-plots. Results showed that very late sowing reduced grain, straw and biological yields of wheat though increased harvest index in both study years. Significant interaction was perceived between sowing time and varieties for grain yield with HD 2967 recorded highest grain yield (5.0 t/ha) under normal sowing. It also exhibited highest yield reduction (18\%) owing to very late sowing. On an average of two years, heat resistant varieties exhibited lower grain yield reduction (5.4\% in WR 544 and $2.3 \%$ in HD 3059) under delayed planting. Non-significant effect of $\mathrm{Zn}$ was seen on grain, straw and biological yields though numerically higher value of above traits was found with soil application of $\mathrm{ZnSO}_{4} .7 \mathrm{H}_{2} \mathrm{O} @ 25 \mathrm{~kg} / \mathrm{ha}+$ foliar spray of $0.5 \%$ $\mathrm{ZnSO}_{4}$ at anthesis stage treatment. Three foliar sprays of $0.5 \% \mathrm{ZnSO}_{4}$ at boot, anthesis and grain filling stage has registered the highest PFP as well as highest $\mathrm{ZnMEI}$ of externally applied $\mathrm{Zn}$ fertilizer though it was very closely followed by other $\mathrm{Zn}$ levels. 


\section{Introduction}

Wheat is most important cereal crop of world including our country India. The wheat crop can be grown in diverse agro-climatic conditions mainly owing to its wider adaptability as well as social acceptability. According to Ma et al., (2008) wheat related food items gives around $20 \%$ of dietary $\mathrm{Zn}$ to Chinese population. India has the largest area under wheat (31.2 Mha) and has a production and productivity of $95.9 \mathrm{Mt}$ and $3.08 \mathrm{t} / \mathrm{ha}$, respectively (DES, 16). In is unequivocal that Wheat's encounter with sub-optimal temperatures at germination and emergence and supra-optimal temperatures during grain growth phase narrow down grain number/spike as well as produces grains with much lower test weight. In Indo-Gangetic Plains (IGPs) delayed harvesting of long duration rice and cotton exposes grain filling of wheat to terminal heat stress (Singh et al., 2017). Moreover, India's proximity to the equator expose wheat to high temperatures (exceeding $35^{\circ} \mathrm{C}$ ) during grain development stage. Temperature has a key role in overall functioning of crops plants including wheat as it affects growth and development, dry matter accumulation and partitioning, photosynthesis, respiration, transpiration as well as root growth. It is also stated that wheat production in developing countries will reduce by 20 $30 \%$ owing to temperature increases under global climate change (Lobell et al., 2008).

Yildirim et al. (2013) planted four bread wheat genotypes (Balatilla, Seri 82, 84CZT04 and HP-1744) and their full diallel design hybrids under normal and late sown stressed condition. They observed that under late planting conditions, grain yield was reduced by $3.03 \mathrm{~g} / \mathrm{plant}(48 \%)$ in parent and by 5.03 $\mathrm{g} /$ plant $(53 \%)$ in hybrids. Significantly intense effect of stress condition was more apparently visible in traits like spike number (26\%), spike grain number $(29 \%)$ and plant grain number $(48 \%)$. Though, reductions in the grain weight and grain filling rate and duration were minimal as compared to the abovementioned traits. So it is clear that reduction in grain yield mainly comes from traits determined during pre-anthesis period under stressed conditions. Their findings ultimately showed that the pre-anthesis period has a greater effect on grain yield than the grain-filling period under stressed conditions compared with non-stressed conditions. In heat stressed wheat superfluous generation of reactive oxygen species (ROS) changes cellmembrane structure which results in loss of function and increases cell-membrane leakiness (Wahid et al., 2007). Zinc (Zn) is a pivotal micronutrient and is an intrinsic part of antioxidant enzyme $\mathrm{Cu}-\mathrm{Zn}$ superoxide dismutase (Cu-Zn SOD) that degrades toxic superoxide radical in the cell. Thus, it provides structural and functional integrity of bio-membranes and is also required for other cellular functions like protein metabolism, gene expression, photosynthetic $\mathrm{C}$ metabolism and IAA metabolism (Marschner, 1998). $\mathrm{Zn}$ fertilization has increased grain yield of spring wheat genotypes with an average value of 883 and $913 \mathrm{~kg} / \mathrm{ha}$ at Karaj and Isfahan locations, respectively (Khoshgoftarmanesh et al., 2009).

Differential responses of wheat varieties have been found with respect to sowing time as well as to their response to externally applied $\mathrm{Zn}$. It has also been proved that wheat crop has genotypic differences for their $\mathrm{Zn}$ use efficiency (Peck and McDonald, 2010). In light of above facts present investigation was conducted to find out the effect of $\mathrm{Zn}$ application on the productivity $\mathrm{Zn}$ use efficiency of spring wheat varieties under timely and very late sown conditions.

\section{Materials and Methods}

Field experiments were conducted during rabi seasons of 2013-14 and 2014-15 at the Indian Agricultural Research Institute, New Delhi 
(latitude $28^{\circ} 40^{\prime} \mathrm{N}$; longitude $77^{\circ} 12^{\prime} \mathrm{E}$; altitude $228.6 \mathrm{~m}$ above mean sea level). On an average of two years, crop received 206.7 and $204.7 \mathrm{~mm}$ rainfall and the highest average growing temperature of 24.5 and $27.0{ }^{\circ} \mathrm{C}$ for normal and very late sowing, respectively. The soil of experimental field was sandy clay loam in texture, low in organic $\mathrm{C}(0.43 \%)$ and available $\mathrm{N}(182.5 \mathrm{~kg} / \mathrm{ha})$, medium in available $\mathrm{P}(17.3 \mathrm{~kg} / \mathrm{ha})$, high in available $\mathrm{K}$ (320.5 kg/ha) and medium in available $\mathrm{Zn}$ (1.45 mg/kg of soil). The $\mathrm{pH}$ of soil was 7.6 . Two sowing times, normal (19 November in year 2013-14 and 25 November in year 2014-15) and very late (26 December in year 2013-14 and 2 January in year 2014-15), three wheat varieties (HD 2967, WR 544 and HD 3059) and four levels of $\mathrm{ZnSO}_{4} \cdot 7 \mathrm{H}_{2} \mathrm{O}$ application (control, $25 \mathrm{~kg} / \mathrm{ha}$ soil application, three foliar sprays of $\mathrm{ZnSO}_{4} .7 \mathrm{H}_{2} \mathrm{O} @ 0.5 \%$ at booting, anthesis and grain filling stage, 25 $\mathrm{kg} / \mathrm{ha}$ soil application + one foliar spray of $\mathrm{ZnSO}_{4} .7 \mathrm{H}_{2} \mathrm{O}$ @ $0.5 \%$ at anthesis stage) were taken for investigation. In all there were twenty four treatment combinations set in a three times replicated split-plot design with two factors (sowing time and variety) in the main-plot, third factor $\left(\mathrm{ZnSO}_{4} \cdot 7 \mathrm{H}_{2} \mathrm{O}\right.$ application) in sub-plot.

A pre-sowing irrigation was applied to the field to ensure adequate soil moisture during wheat sowing. The field was cultivated twice with disc harrow followed by rotavator and a fine seed bed was obtained by two operations through cultivator followed by planking. Recommended package of practices were followed forcultivation of normal and late sown wheat crop, respectively. Soil application of $\mathrm{ZnSO}_{4} \cdot 7 \mathrm{H}_{2} \mathrm{O}$ was done as per treatment before sowing of wheat except in control (no $\mathrm{Zn}$ application). Foliar sprays of $\mathrm{ZnSO}_{4} .7 \mathrm{H}_{2} \mathrm{O}$ were made as per the treatment and a spray volume of 500 litres/ha was used. The irrigations were applied as per crop need and weather conditions. At maturity, net-plot area was harvested and total biomass weight was measured for each plot. After threshing of crop grain yield per plot was measured. The weight of wheat straw was obtained by subtracting the grain yield from the total biomass yield. All the above yields were finally expressed in $t / h a$. Harvest index was calculated as a percentage of grain yield from total biological yield. The estimated values of partial factor productivity (PFP), zinc harvest index (ZHI) and zinc mobilization efficiency index (ZMEI) of applied Zn were computed using the following expressions as suggested by Fageria and Baligar (2003), Dobermann (2005) and Pooniya and Shivay (2013).

\section{Partial factor productivity (PFP)}

The Partial factor productivity (PFP) of applied $\mathrm{Zn}$ was calculated as per equation given below:

$\mathrm{PFP}=\frac{\text { Yield under treatment }(\mathrm{kg} / \mathrm{ha})}{\text { Amount of nutrient added }(\mathrm{kg} / \mathrm{ha})}$

\section{Zinc harvest index (ZnHI)}

The zinc harvest index ( $\mathrm{ZnHI})$ was calculated as the equation given below and was expressed in percentage terms.

$\mathrm{ZnHI}=\frac{\mathrm{Zn}_{\mathrm{s}}}{\mathrm{Zn}_{\mathrm{t}}} \times 100$

Where, $\mathrm{Zn}_{\mathrm{s}}=\mathrm{Zn}$ uptake by grain at harvest

$\mathrm{Zn}_{\mathrm{t}}=\mathrm{Zn}$ uptake by whole crop (grain + straw) at harvest

\section{Zinc mobilization efficiency index (ZnMEI)}

The zinc mobilization efficiency index (ZnMEI) was calculated as the equation given below:

$\mathrm{ZnMEI}=\frac{\text { Zn concentration in grain }(\mathrm{ppm})}{\mathrm{Zn} \text { concentration in straw }(\mathrm{ppm})}$ 
The statistical analysis of data was done using analysis of variance (ANOVA) technique for split-plot design taking two factors (sowing time and variety) in main-plots and four levels of $\mathrm{ZnSO}_{4} .7 \mathrm{H}_{2} \mathrm{O}$ application in sub-plots. The treatment means were compared using least significant difference (LSD) test at $\mathrm{p} \leq 0.05$ (Gomez and Gomez, 1984).

\section{Results and Discussion}

\section{Crop yields and harvest index}

In both the study years (2013-14 and 2014$15)$, very late sowing significantly reduced grain, straw and biological yields of wheat crop though increased harvest index over normal sowing (Table 1). The early and timely sown wheat crop has more growing time as compared to the late planted crop. Therefore, owing to longer growing season timely sown wheat crop not only gives the higher grain, straw and biological yields but also completes its life span before the advance of later season abiotic (heat and drought) and biotic stresses (Gill et al., 2013). The reduction in productivity traits of delayed planted wheat may be owing to high temperature under very late sowing. Heat stress reduces photosynthesis through disruption in the structure and function of chloroplasts and reductions in chlorophyll content (Wahid et al., 2007). A reduction in photosynthesis under heat stress leads to reduced growth, accelerated leaf senescence and decreased grain yield in wheat (Wang et al., 2011). It was observed that high temperature $\left(>30^{\circ} \mathrm{C}\right)$ during grain development stage is a major cause in mitigation of wheat grain and biomass productivity (Zhao et al., 2007). It has been reported that wheat crop require an optimum temperature range of 12 to $22^{\circ} \mathrm{C}$ for anthesis and grain filling (Shewry, 2009). Wheat crop exposed to $>24^{\circ} \mathrm{C}$ temperature during reproductive stage recorded significantly lower grain yield and yield reduction further continued with increasing duration of exposure to high temperature (Prasad and Djanaguiraman, 2014). Significantly higher grain yield (3.9 and $3.4 \mathrm{t} / \mathrm{ha}$ ), straw yield (10.4 and 9.4 t/ha) and biological yield (14.3 and $12.9 \mathrm{t} / \mathrm{ha}$ ) of wheat crop were obtained with November 15 sown crop as compared to December 5 sown crop at Ludhiana and Bathinda locations of Punjab, respectively (Gill et al., 2013). Such higher level of yields might be owing to higher vegetative growth, more tiller production under low growing season temperature during vegetative phase, higher radiation use efficiency and yield attributes.

Among wheat varieties, HD 2967 produced significantly highest grain, straw and biological yields followed by HD 3059. No significant effect of variety factor was seen on the harvest index. However, numerically higher value of harvest index was noticed with WR 544 variety. The interaction between sowing time and variety on grain yield of wheat was found significant in both the years of study (Table 2). On an average of two years under normal sowing, HD 2967 recorded highest grain yield $(5.0$ t/ha) followed by HD 3059 (4.3 t/ha) and least was attained with WR 544 (3.7 t/ha). The highest grain yield reduction of $18 \%$ was found in HD 2967, though WR 544 and HD 3059 also showed 5.4 and $2.3 \%$ reductions, respectively due to late planting. Maximum grain yield $\left(226 \mathrm{~g} / \mathrm{m}^{2}\right)$ and harvest index $(34.7 \%)$ of wheat were obtained with Sardari genotype (heat tolerant, October planted) and minimum grain yield $\left(115.5 \mathrm{~g} / \mathrm{m}^{2}\right)$ and harvest index $(26.5 \%)$ were obtained with Saisonez genotype (heat susceptible, November planted) due to post-anthesis heat stress (Taghizadeh and Sharifi, 2010). On an average of ten wheat genotypes (HI 1563, HD 2987, Kundan, Raj 4238, GW 273, HD 2967 NW 1012, DBW 14, Halna and HD 2733) 
$30 \%$ reduction in wheat's grain yield was recorded due to delayed sowing. Among the genotypes, HI 1563 has shown the maximum grain yield reduction (33\%) while the minimum (20\%) has shown by Raj 4238 due to its heat resistance nature. Genotype HD2987 showed maximum grain yields 4.8 and $3.3 \mathrm{t} / \mathrm{ha}$ under timely and very late sown conditions, respectively Dwivedi et al., (2015). Zn application treatments on an average increased grain and straw yields of wheat by 3.5 and $3.6 \%$, respectively over control though the difference among them was found statistically non-significant (Table
1). Zn levels has not significantly altered harvest index of wheat. Among $\mathrm{Zn}$ application treatments, soil application of $\mathrm{ZnSO}_{4} .7 \mathrm{H}_{2} \mathrm{O} @ 25 \mathrm{~kg} / \mathrm{ha}+$ foliar spray of $0.5 \% \mathrm{ZnSO}_{4}$ at anthesis stage recorded numerically highest biological yield as compared to other treatments including control though it was found on par with other $\mathrm{Zn}$ levels in both the years of study. This might be due to improvement in the bioavailable $\mathrm{Zn}$ in the soil due to compound effect of externally applied $\mathrm{Zn}$ through $\mathrm{ZnSO}_{4}$ and through the sufficient level of soil available $\mathrm{Zn}(1.45 \mathrm{mg} / \mathrm{kg}$ of soil).

Table.1 Grain, straw and biological yields and harvest index of wheat as influenced by sowing time, variety and $\mathrm{Zn}$ application during 2013-14 and 2014-15

\begin{tabular}{|c|c|c|c|c|c|c|c|c|}
\hline \multirow[t]{2}{*}{ Treatment } & \multicolumn{2}{|c|}{$\begin{array}{l}\text { Grain yield } \\
\text { (t/ha) }\end{array}$} & \multicolumn{2}{|c|}{$\begin{array}{c}\text { Straw yield } \\
\text { (t/ha) }\end{array}$} & \multicolumn{2}{|c|}{$\begin{array}{l}\text { Biological yield } \\
\text { (t/ha) }\end{array}$} & \multicolumn{2}{|c|}{$\begin{array}{c}\text { Harvest index } \\
(\%)\end{array}$} \\
\hline & 2013-14 & 2014-15 & 2013-14 & 2014-15 & 2013-14 & 2014-15 & 2013-14 & 2014-15 \\
\hline \multicolumn{9}{|l|}{ Sowing time } \\
\hline Normal & 4.40 & 4.27 & 7.91 & 7.80 & 12.31 & 12.06 & 35.9 & 35.7 \\
\hline Very late & 4.05 & 3.83 & 5.62 & 5.50 & 9.67 & 9.33 & 42.1 & 41.1 \\
\hline SEm \pm & 0.07 & 0.07 & 0.20 & 0.27 & 0.22 & 0.24 & 0.8 & 1.1 \\
\hline $\mathrm{CD}(\mathrm{P}=0.05)$ & 0.21 & 0.21 & 0.63 & 0.85 & 0.69 & 0.76 & 2.5 & 3.4 \\
\hline \multicolumn{9}{|l|}{ Cultivar } \\
\hline HD 2967 & 4.65 & 4.46 & 7.30 & 7.16 & 11.95 & 11.62 & 39.1 & 38.6 \\
\hline WR 544 & 3.68 & 3.52 & 5.84 & 5.55 & 9.52 & 9.08 & 39.2 & 39.5 \\
\hline HD 3059 & 4.36 & 4.15 & 7.14 & 7.23 & 11.50 & 11.39 & 38.6 & 37.2 \\
\hline $\mathrm{SEm} \pm$ & 0.08 & 0.08 & 0.24 & 0.33 & 0.27 & 0.30 & 1.0 & 1.3 \\
\hline $\mathrm{CD}(\mathrm{P}=\mathbf{0 . 0 5})$ & 0.26 & 0.26 & 0.77 & 1.04 & 0.84 & 0.94 & NS & NS \\
\hline \multicolumn{9}{|l|}{$\mathrm{ZnSO}_{4 .} .7 \mathrm{H}_{2} \mathrm{O}$ application } \\
\hline Control (0) & 4.16 & 3.90 & 6.55 & 6.50 & 10.70 & 10.41 & 39.4 & 38.1 \\
\hline SA 25 kg/ha & 4.22 & 4.02 & 6.80 & 6.68 & 11.02 & 10.70 & 38.8 & 38.1 \\
\hline $3 F{ }^{*}$ & 4.24 & 4.12 & 6.80 & 6.70 & 11.04 & 10.81 & 39.0 & 38.7 \\
\hline SA $25 \mathrm{~kg} / \mathrm{ha}+1 \mathrm{FS} * *$ & 4.30 & 4.15 & 6.90 & 6.72 & 11.20 & 10.87 & 38.8 & 38.9 \\
\hline SEm \pm & 0.06 & 0.07 & 0.13 & 0.16 & 0.14 & 0.15 & 0.6 & 0.9 \\
\hline $\mathrm{CD}(\mathrm{P}=\mathbf{0 . 0 5})$ & NS & NS & NS & NS & NS & NS & NS & NS \\
\hline
\end{tabular}

SA, soil application; 3FS*, three foliar sprays at booting, anthesis and grain filling stage; $1 \mathrm{FS} * *$, one foliar spray at anthesis 
Table.2 Interaction effect between sowing time and variety on grain yield of wheat during 2013-14 and 2014-15

\begin{tabular}{|c|c|c|c|c|}
\hline \multirow{3}{*}{$\begin{array}{l}\text { Treatment } \\
\text { Cultivar }\end{array}$} & \multicolumn{4}{|c|}{ Grain yield (t/ha) } \\
\hline & \multicolumn{2}{|c|}{ 2013-14 } & \multicolumn{2}{|c|}{ 2014-15 } \\
\hline & Normal & $\begin{array}{l}\text { Very } \\
\text { late }\end{array}$ & Normal & $\begin{array}{l}\text { Very } \\
\text { late }\end{array}$ \\
\hline HD 2967 & 5.05 & 4.26 & 4.92 & 4.01 \\
\hline WR 544 & 3.75 & 3.60 & 3.61 & 3.43 \\
\hline HD 3059 & 4.42 & 4.29 & 4.27 & 4.04 \\
\hline SEm \pm & \multicolumn{2}{|c|}{0.11} & \multicolumn{2}{|c|}{0.12} \\
\hline $\mathrm{CD}(\mathrm{P}=0.05)$ & \multicolumn{2}{|c|}{0.36} & \multicolumn{2}{|c|}{0.37} \\
\hline
\end{tabular}

Table.3 Zn harvest index (Zn HI) and Zn mobilization efficiency index (ZnMEI) of wheat as influenced by sowing time, variety and Zn application during 2013-14 and 2014-15

\begin{tabular}{|c|c|c|c|c|}
\hline \multirow[t]{2}{*}{ Treatment } & \multicolumn{2}{|c|}{ Zn HI (\%) } & \multicolumn{2}{|c|}{ ZnMEI } \\
\hline & 2013-14 & 2014-15 & 2013-14 & 2014-15 \\
\hline \multicolumn{5}{|l|}{ Sowing time } \\
\hline Normal & 41.0 & 41.7 & 1.23 & 1.28 \\
\hline Very late & 47.7 & 47.8 & 1.25 & 1.31 \\
\hline $\mathrm{SEm} \pm$ & 0.8 & 1.2 & 0.01 & 0.01 \\
\hline $\mathrm{CD}(\mathrm{P}=\mathbf{0 . 0 5})$ & 2.5 & 3.6 & NS & 0.03 \\
\hline \multicolumn{5}{|l|}{ Cultivar } \\
\hline HD 2967 & 44.4 & 44.6 & 1.24 & 1.27 \\
\hline WR 544 & 44.9 & 46.3 & 1.26 & 1.32 \\
\hline HD 3059 & 43.8 & 43.4 & 1.23 & 1.29 \\
\hline $\mathbf{S E m} \pm$ & 1.0 & 1.4 & 0.01 & 0.01 \\
\hline $\mathrm{CD}(\mathrm{P}=\mathbf{0 . 0 5})$ & NS & NS & 0.02 & 0.03 \\
\hline \multicolumn{5}{|l|}{$\mathrm{ZnSO}_{4 .} 7 \mathrm{H}_{2} \mathrm{O}$ application } \\
\hline Control (0) & 45.3 & 44.9 & 1.23 & 1.29 \\
\hline SA $25 \mathrm{~kg} / \mathrm{ha}$ & 44.2 & 44.4 & 1.24 & 1.28 \\
\hline $3 F S^{*}$ & 44.0 & 44.7 & 1.26 & 1.29 \\
\hline SA $25 \mathrm{~kg} / \mathrm{ha}+1 \mathrm{FS} * *$ & 43.9 & 45.1 & 1.24 & 1.31 \\
\hline SEm \pm & 0.7 & 0.9 & 0.01 & 0.01 \\
\hline $\mathrm{CD}(\mathrm{P}=0.05)$ & NS & NS & 0.02 & NS \\
\hline
\end{tabular}

SA: Soil application, 3FS*: Three foliar sprays @ 0.5\% at boot, anthesis and grain filling stage, 1FS**: One foliar spray@ $0.5 \%$ at anthesis 
Fig.1 Partial factor productivity (PFP) of wheat as influenced by sowing time, variety and $\mathrm{Zn}$ application

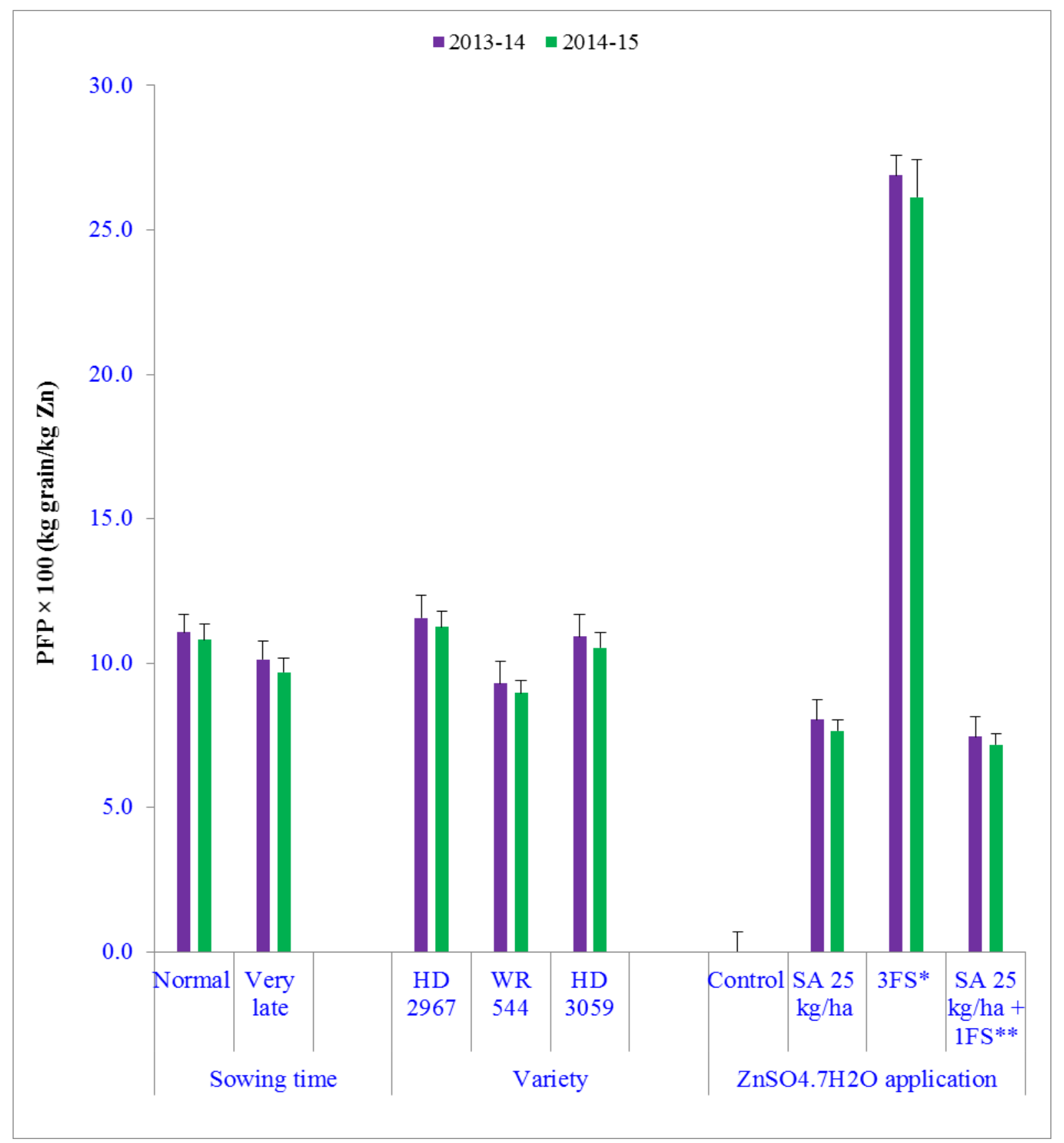

SA: Soil application, 3FS*: Three foliar sprays @ 0.5\% at boot, anthesis and grain filling stage, 1FS**: One foliar spray @ $0.5 \%$ at anthesis

In a long term experiment on the rice-wheat system, Gami et al., (2001) found nonsignificant improvement in grain yields of rice and wheat with $\mathrm{P}, \mathrm{K}, \mathrm{Zn}$ and $\mathrm{S}$ applications due to adequate native supply of these nutrients. However, in $\mathrm{Zn}$ deficient soil $(0.54 \mathrm{mg} / \mathrm{kg})$, significantly higher grain and straw yields and harvest index of wheat were 
reported with the $\mathrm{Zn}$ applications (Keram et al., 2013). Similarly wheat cultivars viz., Bakhar-2002, Shafaq-2006, Saher-2006, Faisalabad-2008 and Lasani-2008 were grown with $\mathrm{Zn}$ applications levels $(0,4,8$ and 12 $\mathrm{kg} / \mathrm{ha}$ ). Soil application of $\mathrm{Zn}$ significantly improved the maximum yield related traits of all wheat cultivars as compared with control. The plots receiving $\mathrm{Zn}$ at 8 and $12 \mathrm{~kg} / \mathrm{ha}$ observed higher wheat grain yield along with higher grain $\mathrm{Zn}$ concentration (Nawaz et al., 2015).

\section{Zinc use efficiencies}

During both the years of study partial factor productivity (PFP) was affected by sowing time, varieties and $\mathrm{Zn}$ application levels (Fig. 1). Among sowing times, very late sowing has reduced PFP of wheat as compared to normal sowing in both the years of investigation. Among varieties, HD 2967 recorded highest PFP followed by HD 3059 and least was found with WR 544 in both the years of study. The treatment three foliar sprays of $0.5 \% \mathrm{ZnSO}_{4}$ at boot, anthesis and grain filling stage has registered the highest PFP of externally applied $\mathrm{Zn}$ fertilizer.

Among different wheat varieties, higher partial factor productivity (PFP) and agronomic efficiency (AE) were registered with HD 2967 followed by PBW 343 (Ghasal et al., 2017). According to them, higher PFP and AE in HD 2967 and PBW 343 could be owing to their improved growth and productivity as compared to other varieties. Zn harvest index was significantly affected by the sowing time and non-significantly by the cultivars and $\mathrm{Zn}$ application treatments (Table $3)$. The late sowing has significantly increased the $\mathrm{Zn}$ harvest index of wheat crop in both the years of study over normal sown crop. Among variety tested, WR 544 recorded numerically higher value of $\mathrm{Zn}$ harvest index as compared to other tested varieties (HD
2967 and HD 3059). Ghasal et al., (2017) also found non-significant improvement in $\mathrm{Zn}$ harvest index of wheat varieties due to external $\mathrm{Zn}$ application. The data related to the $\mathrm{Zn}$ mobilization efficiency index (ZnMEI) has been given in table 3 . Over two years of study, differential influence of sowing time was seen on the ZnMEI. In the year 2013-14, two sowing times were found on par with respect to ZnMEI. However, in year 2014-15, statistically higher ZnMEI was observed with very late sowing. Among cultivars, WR 544 has shown significantly higher ZnMEI in 2013-14 but found at par with HD 2967. In the year 2014-15, WR 544 again has exhibited the highest ZnMEI and found at par with HD 3059. In first year, three foliar sprays of $0.5 \% \mathrm{ZnSO}_{4}$ at boot, anthesis and grain filling stage has registered the highest $\mathrm{ZnMEI}$, though in second year all the $\mathrm{Zn}$ application levels were found statistically similar. In a study with different wheat genotypes Ghasal et al., (2017) observed the highest $\mathrm{Zn}$ mobilization efficiency index (ZnMEI) with HD 2967 variety and least in HD 2894 variety. They also noticed that ZnMEI was on par among different $\mathrm{Zn}$ fertilization treatments however the numerically higher values were seen in combined Zn (soil + plant) applications.

The results of this experimentation concludes that very late sowing reduces grain, straw and biomass yields and PFP of externally applied $\mathrm{Zn}$ in wheat as compared to normal sowing though it has also improved $\mathrm{Zn}$ harvest index as well as ZnMEI of wheat. Terminal heat stress under delayed planting hastens wheat's growth and production cycle and reduces duration of different phenological stages of crop. The heat resistant varieties (HD 3059 and WR 544) have shown their superiority for maintenance of yield under heat stress. The externally applied $\mathrm{Zn}$ was not able create any major improvement in wheat yields under ample soil available $\mathrm{Zn}$. However, three foliar 
sprays of $0.5 \% \mathrm{ZnSO}_{4}$ at boot, anthesis and grain filling stage has registered the highest PFP as well as highest ZnMEI of externally applied $\mathrm{Zn}$ fertilizer though it was very intimately followed by other Zn levels.

\section{References}

DES. 2016. Area, production and productivity of crops. Agricultural statistics at a glance 2016, pp. 91, Directorate of Economics and Statistics, Department of Agriculture and Cooperation, Government of India.

Dobermann, A. 2005. Nitrogen use efficiency-State of the art. (In) IFA International Workshop on EnhancedEfficiency of Fertilizers, 28-30 June, Frankfurt, Germany, pp 1-18.

Dwivedi, S. K., Kumar, S. and Prakash, V. 2015. Effect of late sowing on yield and yield attributes of wheat genotypes in EIGP. Journal of Agricultural Research 2(4):304-306.

Fageria, N. K. and Baligar, V. C. 2003. Methodology for evaluation of lowland rice genotypes for nitrogen use efficiency. Journal of Plant Nutrition 26: 1315-33.

Gami, S. K., Ladha, J. K., Pathak, H., Shah, M. P., Pasuquin, E., Pandey, S. P., Hobbs, P. R., Joshy, D. and Mishra, R. 2001. Long-term changes in yield and soil fertility in a twenty-year rice-wheat experiment in Nepal. Biology and Fertility of Soils34: 73-78.

Ghasal, P. C., Shivay, Y. S., Pooniya, V., Choudhary, M. and Verma, R. K. 2017. Zinc accounting for different varieties of wheat (Triticum aestivum) under different source and methods of application. Indian Journal of Agricultural Sciences 87 (9): 11111116.

Gill, K. K., Kaur, N. and Babuta, R. 2013. Crop growth behaviour and yield characteristics of wheat (Triticum aestivum L.) in two different agroclimatic zones of Punjab. Journal of Agricultural Physics 13(2): 126-132.

Gomez, K. A. and Gomez, A. A. 1984. Statistical procedure for agricultural Research, and Education. John Willey and Sons, New York, U.S.A. pp: 241271.

Keram, K. S., Sharma, B. L., Sharma, G. D. and Thakur, R. K. 2013. Impact of zinc application on its translocation into various plant parts of wheat and its effect on chemical composition and quality of grain. Scientific Research and Essays 8(45): 2218-2226.

Khoshgoftarmanesh, A.H., Sadrarhami, A., Sharifi, H.R. Afiuni, D. and Schulin, R. 2009. Selecting zinc-efficient wheat genotypes with high grain yield using a stress tolerance index. Agronomy Journal 101: 1409-1416.

Lobell, D. B., Burke, M. B., Tebaldi, C., Mastrandrea, M. D., Falcon, W. P. and Naylor, R. L. 2008. Supporting online materials for Prioritizing climate change adaptation needs for food security in 2030. Science 319:607-610.

Ma. G. S., Jin, Y., Li Y. P., Zhai, F. Y., Kok, F., Jacobsen, E. and Yang, X. G. 2008. Iron and zinc deficiencies in China: what is a feasible and cost-effective strategy? Public Health Nutrition 11:632-638.

Marschner, H. 1998. Mineral nutrition of higher plants, pp.347-364, Academic Press, London.

Nawaz, H., Hussain, N., Yasmeen, A., Arif, M., Hussain, M., Rehmani, M. I. A., Chatta, M. b. and Ahmad, A. 2015. Soil applied zinc ensures high production and net returns of divergent wheat cultivars. Journal of Environmental and Agricultural Sciences 2: 1-4.

Peck, A. W. and McDonald, G. K. 2010. Adequate zinc nutrition alleviates the 
adverse effects of heat stress in bread wheat. Plant and Soil 337:355-374

Pooniya, V. and Shivay, Y. S. 2013. Enrichment of basmati rice grain and straw with zinc and nitrogen through ferti-fortification and summer green manuring under Indo-Gangetic plains of India. Journal of Plant Nutrition 36(1): 91-117.

Prasad, P. V. V. and Djanaguiraman, M. 2014. Response of floret fertility and individual grain weight of wheat to high temperature stress: sensitive stages and thresholds for temperature and duration. Functional Plant Biology 41:12611269. doi:10.1071/FP14061

Shewry, P. R.2009. Wheat. Journal of Experimental Botany 60:1537-1553. doi:10.1093/jxb/erp058

Singh, M., Sidhu, H. S., Mahal, J. S., Manes, G. S., Jat, M. L., Mahal, A. K., Singh, P. and Singh, Y. 2017. Relay sowing of wheat in the cotton-wheat cropping system in north-west India: technical and economic aspects. Experimental Agriculture 53(4): 539-552.

Taghizadeh, R. and Sharifi, R. S. 2010.
Effects of post-anthesis heat stress on yield and yield attributes in wheat ( $T$. aestivum) genotypes. Journal of Food, Agriculture and Environment 8 (2): 775-777.

Wahid, A., Gelani, S., Ashraf, M. and Foolad, M. R. 2007. Heat tolerance in plants: an overview. Environmental and Experimental Botany 61: 199-23.

Wang, X., Cai, J., Jiang, D., Liu, F., Dai, T. and Cao, W. 2011. Pre-anthesis hightemperature acclimation alleviates damage to the flag leaf caused by postanthesis heat stress in wheat. Journal of Plant Physiology168: 585-93.

Yildirim, M., Koc, M., Akinci, C. and Barutcular, C. 2013. Variations in morphological and physiological traits of bread wheat diallel crosses under timely and late sowing conditions. Field Crops Research 140: 9-17.

Zhao, H., Dai, T., Jing, Q., Jiang, D. and Cao, W. 2007. Leaf Senescence and Grain Filling Affects by Post Anthesis High Temperatures in Two Different Wheat Cultivars. Plant Growth Regulation 51(2): 149-158.

\section{How to cite this article:}

Amit Kumar, Shiva Dhar, Anchal Dass and Ranjana. 2020. Sowing Time and Zn Application Effects on Productivity and Zn Use Efficiency of Wheat (Triticum aestivum L.) Varieties. Int.J.Curr.Microbiol.App.Sci. 9(01): 803-812. doi: https://doi.org/10.20546/ijcmas.2020.901.086 